\title{
An Empirical Study of Blended Teaching Model in University English Teaching
}

\author{
Shenying Jiang, Danli Li \\ College of Foreign Languages, Shenyang Aerospace University, Shenyang, China \\ Email: bettybest2006@163.com
}

Received June $11^{\text {th }}$ 2012; revised July $20^{\text {th }}$, 2012; accepted July $30^{\text {th }}, 2012$

\begin{abstract}
It has been seven years since Education Ministry issued College English Curriculum Trail Requirements. It is of manifest necessity to conduct a survey about the effective application under blended teaching model in common university. This paper adopts consecutive three years' empirical study of blended teaching model and analyzes the data from both English teachers' and students' viewpoint. Then it discovers some problems and proposes corresponding suggestions with the purpose to facilitate the improvement of the English teaching in universities.
\end{abstract}

Keywords: Blended Teaching Model; English Teaching; Empirical Study

\section{Introduction}

With the deeper development of the education reform In 2004 the Education Ministry issued College English Curriculum Requirements (For Trial Implementation) and pointed out "The new model should be built on modern information technology, particularly network technology, so that English language teaching will be, to a certain extent, free from the constraints of time or place and geared towards students' individualized and autonomous learning.” In this requirement, it showed that new teaching model required college English teachers to combine regular teaching with multimedia teaching. In addition, they should link students' self-learning with their guide. Furthermore they must pay more attention to not only what they taught but also how they taught. Under this model the students can improve their English level in listening, speaking, reading, writing and translating.

The topic of this thesis is chosen. But whether the hardware of colleges and students' skills to use the internet and learning styles are appropriate to carry out blended learning remains unanswered. If all these conditions are good, how do teachers efficiently carry out their blended teaching? What kinds of roles do teachers play? This paper is based on blended teaching model and analyze datum through questionnaire. Then it tries to find some problems and give some suggestions in order that college English teaching in China is going smoothly.

\section{Research Design}

Although blended teaching is a new pattern, it has aroused the attention at home and abroad, because it is in accordance with the current learning paradigm shift (from teacher-centered to student-centered change). Some foreign researchers have done researches in the field of higher education and enterprise training. In China it was Kekang He (2004a, 2004b) who firstly proposed it in Journal of China Educational Technology. Since then the colleges and universities have changed a lot in English teaching. It is necessary to survey the present situation of the application under blended teaching model in common college and university. The concrete questions of the survey are as follows:

What is the attitude of common college English teachers and students towards blended teaching?

How is blended teaching model applied?

How is the overall effect of teaching under blended teaching?

Teachers participating in this study (in July, 2010) are 30 comprehensive English teachers who come from Shenyang Aerospace University and teach freshman and sophomore. The age of them is from 28 to 55 . Their titles of a technical post are composed of 1 professor, 11 vice professors and 18 lecturers. The results of the 30 questionnaires are effective.

Besides, there was the feedback of 1221, 1342, 1538 questionnaire in year 2008, 2009, and 2010 from freshmen in Shenyang Aerospace University.

This paper analyzes the empirical data from both English teachers and students' standing point.

\section{Empirical Analysis of English Teachers' Feedback}

\section{Teachers’ Attitudes to Blended Teaching Model}

When the teachers were asked to answer their attitude to blended teaching model, $70 \%$ of them are positive (approved greatly and $26.66 \%$ approved). They all agreed that bended teaching model were good for the students. It could helpful for students to develop their ability in learning English.

\section{Teachers’ Ability to Use Computer and Internet}

It is necessary to survey English teachers' ability to use computer and internet in modern ages.

Survey showed $86.66 \%$ of English teachers used computers to process words; $100 \%$ received and sent E-mail; $96.66 \%$ sought English materials on the internet; but only $16.66 \%$ used computers to chat with friends and $20 \%$ to edit courseware. It showed that the teachers had ability to use the computer to do some simple things. But they didn't spend much time in editing 
and improving the courseware.

\section{Teaching Methods and Effect of Teaching}

When it comes to the teaching methods that the teachers of intensive reading adopt and the effect that the students get, the surveys' result showed the teaching methods that the teachers took were not diversified. Text explanation and task-based teaching were the most popular methods (100\% and $80 \%)$. Group-discussion was another popular one (76.66\%). Vocabulary explanation was still taken (63.33\%). But percentage of using computer (only 63.33\%) to finish teaching was lower than it had been expected. Only $10 \%$ of the teachers use project-based teaching. As a result self-study ability of students is not improved fully. The teachers and the students do not make full use of computer. The effect of teaching is not satisfied.

\section{Empirical Analysis of Students' Questionnaire \\ Data Resource of Students’ Feedback}

With the purpose to explore the effect of blended teaching model from students' viewpoint, we conducted the survey by using questionnaire among the freshmen during consecutive three years' time at every end of semester after they experienced the blended teaching model for at least half a year time, and collected effective feedback of 1221, 1342, 1538 questionnaire in year 2008, 2009, and 2010. Students are asked to complete the about 10 minutes' survey independently at the semester's last class, and submit the result through paper or online. The freshmen are from different cities in mainland of China and some of them are exchange students from Korea, Arab, and India, etc.

\section{Students' Attitudes to Blended Teaching Model}

The student attitude survey of blended teaching method's result is showed in Table $\mathbf{1}$.

Since College English is kind of compulsory course of all the majors, the freshmen are from almost all kinds of majors in university, we are able to utilize the comprehensive and extensive-reaching student resource and investigate the students' attitudes towards blended teaching model. We ignored the discrepancies of the attitudes from different majors, but consider all of them into one group for the consideration of that all the freshmen have experienced a different study mode in the college compared with the method adopted in high school, and the difference in majors does not play a material part in students' attitude towards the blended teaching model.

\section{Indicator of Blended Teaching Model}

Different from teachers' survey, we chose some other indicators as blended teaching model from student aspect, including the help of text preparation and review by oneself using the provided software from the textbook, the accompanied online system to practice the listening and speaking for each unit, the submission of some assignment such as writing or presentation's power point and report during the teaching and learning process.

We also chose some other indicators students may use in daily life to facilitate the learning ability and stimulate the studying initiative, including the public mailbox online which is usually shared by a class for the transmission of lecture note from teachers or some other school issues, the post digest sent by school or university daily or weekly dependent on students' choices to post the forthcoming events, the transcript release and the notification system enable students to check the examination result online, the communication through school email or other method among students and with teachers about the kinds of issues.

All eight indicators composed the whole blended teaching model faced by students and provided an effective credible result of students' attitude towards the blended teaching model.

\section{Analysis of the Students' Attitudes}

The feedback demonstrated that most of the students consider the blended teaching model was effective and beneficial to them. As for the English text study part, the preparation and review played the almost same importance in study process in about $70 \%$ beneficial percentage for continuous three years' period. The online practice showed a little higher opposite attitude, when asked the reason they reacted oppositely towards the online practice, most of them complained about the usage method of the online practice system and the not fast enough university internet speed, which compelled them to do the ever unit's homework to spend more time or try to do same work twice due to the unsuccessful submission. However, it still

Table 1.

Students' feedback on blended teaching modle.

\begin{tabular}{|c|c|c|c|c|c|c|c|c|c|}
\hline \multirow{2}{*}{$\begin{array}{c}\text { Contents } \\
\text { Percentage }\end{array}$} & \multicolumn{3}{|c|}{ Not Really } & \multicolumn{3}{|c|}{ Neutral } & \multicolumn{3}{|c|}{ Beneficial } \\
\hline & 2008 & 2009 & 2010 & 2008 & 2009 & 2010 & 2008 & 2009 & 2010 \\
\hline Preparation before class & 4.59 & 9.91 & 7.41 & 23.18 & 22.28 & 24.77 & 72.24 & 67.81 & 67.82 \\
\hline Review after class & 1.80 & 5.81 & 13.13 & 24.41 & 20.57 & 19.77 & 73.79 & 73.62 & 67.10 \\
\hline Online listening, speaking, etc. & 16.71 & 11.33 & 5.98 & 14.58 & 14.83 & 15.86 & 68.71 & 73.85 & 78.15 \\
\hline Submission assignment through internet & 18.02 & 20.94 & 15.73 & 16.63 & 17.36 & 25.68 & 65.36 & 61.70 & 58.58 \\
\hline Public mailbox online & 1.80 & 11.10 & 3.97 & 8.03 & 7.90 & 14.50 & 90.17 & 81.00 & 81.53 \\
\hline Post digest (daily or weekly) & 21.70 & 4.69 & 19.44 & 32.60 & 44.26 & 29.45 & 45.70 & 51.04 & 51.11 \\
\hline Transcript/Notification & 3.60 & 2.61 & 3.71 & 4.42 & 17.06 & 5.79 & 91.97 & 80.33 & 90.51 \\
\hline Communication & 19.90 & 10.80 & 16.06 & 25.23 & 30.48 & 16.78 & 54.87 & 58.72 & 67.17 \\
\hline
\end{tabular}


showed that students' attitude towards the online learning very positive for the reason that they may control the academic progress, while some students may not pay enough attention to the preparation or review of textbook, it is a regret that not all students achieve excellent scores by using blended teaching and learning effectively.

As for the other part other than text learning, students held the opinion the most beneficial parts were public mailbox and transcript notification, while they found the post digest and communication less beneficial to them. The reasons for this were diversified. In the internet age, students faced up with kind of information overload and may not pay enough concern on the post digest for the college's events. Some of them chose to focus on study but not extra-curriculum activities, they voluntarily decided to neglect some information or news of events, they felt the post digest was not beneficial to their daily life or study process.

But as for the public mailbox and transcript notification, students showed supportive attitude towards them. These two methods were shortcuts of collecting information and efficient to let students know the of importance information even if they were out of campus. These two parts won the most supportive voice in blended teaching model.

\section{Suggestions}

\section{Strengthening Conceptions of Blended Teaching}

In the study, six conceptions of teaching were identified by Robert. A. Ellis, 2006: 1) Teaching as transmitting concepts of the syllabus; 2) Teaching as transmitting the teachers' knowledge; 3) Teaching as helping students acquire concepts of the syllabus; 4) Teaching as helping students acquire teacher knowledge; 5) teaching as helping students develop conceptions; 6) Teaching as helping students change conceptions. The most significant qualitative shift in the above categories occurs between categories (4) and (5), in which the perspective of the category moves from the teacher to the student.

\section{Strengthening the Conception of the Teacher Role in Teaching}

The teachers play an important role in their teaching. Under the network multimedia teaching environment, the teacher no longer is the knowledge instruction leader, also no longer is the sole source from which students gain knowledge. The teacher is acting organizer and the guide of the teaching environment and the course content. He is a modifier for the study goal of students. He is also a supervisor and controller of what students will learn. He can make a reasonable suggestion for students and help students to establish the appropriate goal.

\section{Strengthening Fostering Students' Self-Study Ability}

Compared with abroad universities, most of our universities focus more on students' scores, especially common colleges. In order to meet the demands of the society after students graduate from their colleges, the teacher must strengthen fostering students' self-study ability. Teachers may often apply projectbased teaching (Figure 1).

From the chat flow it shows that after the teacher and students finish what they should do, on the one hand teacher plays an important role in his teaching. On the other hand students

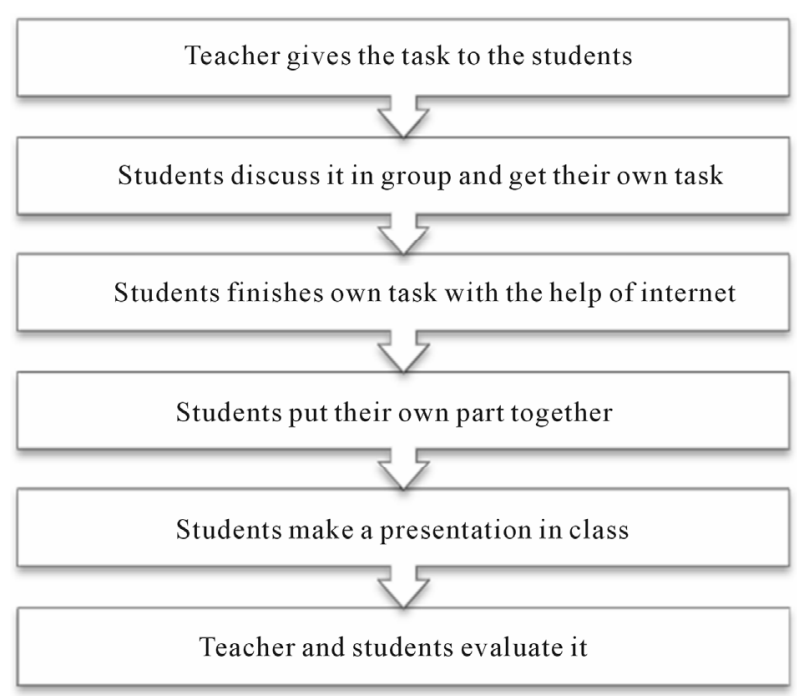

Figure 1.

Flow chart of fostering students' self-study ability.

not only learn how to deal with problems and how to study by themselves, but also learn how to cooperate with others. In this way students' self-study ability is strengthened. Their ability of solving problems and cooperating with others is developed.

\section{Improving Hardware Equipment and Developing Software Resources}

To meet the needs of teachers and students, it is more important for the common colleges and universities to put money into updating hardware equipment to raise the speed of the internet and developing software resources. In order to improve the teaching internet in the university further. System administrators should think seriously student's comments and suggestions, further modifying and improving the design of platform interface interaction so as to make the system operation more accord with the needs of students. Besides they should improve learning function of the internet system, such as providing modifying assignments online and learning related social networking, developing instant questions answered software and so on. They should provide training and technical services to the teachers in order to promote intercommunicating teachers and students online. Only in this way can teachers and students make full use of multimedia and internet

\section{Conclusion}

It can be concluded that bended teaching model is very helpful to teachers and students with the further development of the information technology. Teachers must try to master the use of the computer and make full use of multimedia and internet to carry out teaching so as to make their lessons more diversified, informative, and above all more interesting. In addition, teachers should strengthen conception of their roles and play an important role in teaching.

As saying says, "Give a man a fish, you have fed him for today. Teach a man to fish, and you have fed him for a lifetime.”. For a teacher how to teach is more important than what to teach. The teacher should teach students methods to study rather than contents to study. Last but not the least teacher should try to 
combine the advantage of traditional teaching model with blended teaching model in teaching in order to foster students that society needs.

\section{Acknowledgements}

I want to thank my friend Professor Danli LI, for her guidance and suggestions, in particular, for her encouragement towards this topic, careful assistance regarding revisions, valuable insights, and general support in all areas of the work and study required to complete my thesis. I also thank 30 teachers and more than 4000 students in my university who take part in questionnaire, which helps me finish my paper in time.

\section{REFERENCES}

Education Ministry (2004). College English curriculum requirements (for trial implementation). Shanghai: Shanghai Foreign Language Education Press.

Ellis, R. A. (2006). Teacher conceptions of blended learning, blended teaching and associations with approaches to design. Australasian Journal of Educational Technology, 22, 312-335.

He, K. K. (2004a). New development of educational technology from the viewpoint of blending learning (the first part). CET China Educational Technology, 5-14.

He, K. K. (2004b). New development of educational technology from the viewpoint of blending learning (the second part). CET China Educational Technology, 10-15. 